\title{
Place Leadership and The Social Contract: Re-Examining Local Leadership in the East Midlands
}

\section{Martin Quinn, School of Business, University of Leicester, martin.quinn@le.ac.uk}

Word Count: 7285 (excluding references)

Abstract

This paper uses Social Contract theory to (re) examine attempts to establish leadership roles in the East Midlands, Corby, Leicestershire and Northamptonshire between 19982015. In doing so it makes a unique contribution to the study of place leadership by drawing on classical political theory to explore a contemporary issue in regional debate. To do this the paper explores three stages of leadership development in the East Midlands of England, cutting across scale and place to argue that in order to establish and embed a contract with the locality leaders must take into account both the territorial and relational characteristics of their place. Where the territory had little cohesion, or did not cover a single area of economic functionality it was difficult to establish, or justify, leadership roles in those territories. In areas of economic functionality leadership required the involvement of the Local Government to demonstrate the legitimacy of the contract on offer.

Keywords: Social Contract Theory, Leadership, Local Government, Governance, Place 


\section{Introduction}

This paper explores attempts to establish leadership roles in the economy of the East

Midlands of England (See Map below) and its constituent parts over a period of 17 years $(1998-2015)$.

Figure 1: The East Midlands of England

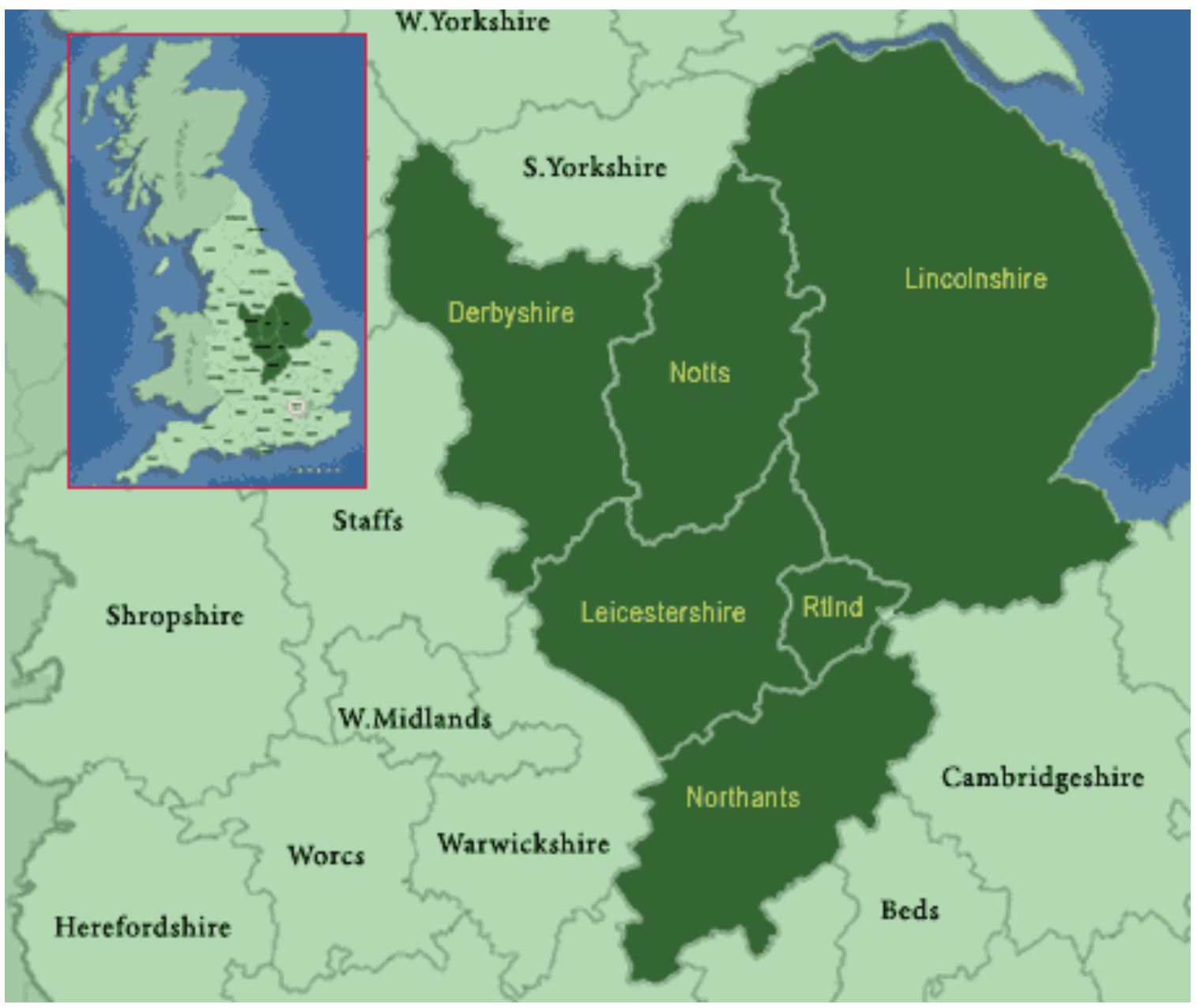

http://www.picturesofengland.com/mapofengland/east-midlands-map.html 
This period covers several different regional and local policy initiatives including Regional Development Agencies (RDAs), Sub-Regional Strategic Partnerships, MultiArea Agreements (MAA), Local Enterprise Partnerships (LEPs) and the establishment of elected mayors. These policies were initiated by the Labour Government's of 1997 2010 and the Coalition Government of 2010 - 2015. As Etherington \& Jones (2009) have demonstrated English regional policy tends to move in cycles between the regional and local (by which we mean County or City-region) tiers and the period in question is no different with economy development efforts shifting between the regional (East Midlands) and local (Leicestershire etc). The paper pays particular attention to the East Midlands between 1998 - 2010, and Leicester and Leicestershire, Corby and Northamptonshire across the whole period. In order to do so, the paper will make use of Social Contract Theory to re-examine data collected during this period and offer a fresh insight into the lessons that can be drawn from the East Midlands. In doing so the paper responds Blanco et al's (2014) call for the study of local practices and how local leadership has emerged and/or failed under a succession of neoliberal economic development polices. The use of Social Contract Theory as a lens through which to examine those successes and failures in the East Midlands provides a method of analysis beyond the boundaries of a single case study.

Social Contract Theory is a classic of political science (Barker 1960, Boucher \& Kelly 1994 Lessnoff 1986). It has not, however, had a prominent role in the studies of regions, place, space or relational networks. When we consider that leadership has also been somewhat underplayed as a factor in regional debates (Collinge \& Gibney 2011, 
Sotarauta et al 2012) a gap emerges in the use of theories from Political Sciences as tools of analysis of regional problems (Jones 2014). Social Contract Theory appears to offer much to those who wish to study the development of place based institutions and economic development policy initiatives. First developed in the middle ages by the likes of Manegold (Lessnoff 1986) Social Contract Theory is concerned with exploring and establishing the ways in which a Government, State or leader can establish a contract with the population it wishes to rule over. This paper will use Social Contract theory to investigate (the lack of) engagement with sub-national institutions and policies in England. England's political traditions draw on the principals of liberty and limited government espoused by enlightenment philosophers such as J.S. Mill (1858) and Bentham (1776). Social Contract theorists, such as Hobbes (1651), Locke (1690) and Rousseau (1762), explore the conditions that are required for populations to submit to political authority (Boucher \&Kelly 1994), usually at the level of the Nation State and, perhaps, most famously expressed in the form of Hobbes' 'Leviathan'. This paper argues that regions in England need to show they are able to bridge the gap between liberty and leviathan by turning to Rousseau - i.e. if a regional leviathan could be seen to provide the conditions for liberty laid out by Mill et al then the populous would be prepared to sign a social contract with it. This paper seeks to establish what those conditions where in an effort to make the lessons drawn from the East Midlands applicable to other regions. To do so it will fuse political theory and regional studies and in doing so seeks to address perennial issues of engagement with sub-national governance in England. 
Locke argued that in order for the people to submit to a Government that Government would need to be able to demonstrate it could provide them with security and protection that the people would not otherwise be able to guarantee. In exchange for this protection the people would be prepared to give up elements of their liberty and transfer power to the Government. From a regional leadership perspective this paper takes this element of transfer and asks what would a regional authority or leader need to offer to its businesses and population in order that they gave over their time and efforts to building the regional economy and it is through this lens that Social Contract Theory is applied to the East Midlands between 1998-2015 in this paper.

The paper broadly agrees with the work of Sotarauta et al (2012) that we should be wary of attributing successful leadership to individuals, and instead concentrate on creating the conditions that allow leaders to emerge and succeed in setting up a contract with a place or network. Indeed the lessons that can be drawn from the period 2007-2010 illustrate just how fragile leadership based on individuals can be and that if local leadership is to be sustainable and a long term contract established then it needs to be able to survive changes in personnel. That said those individual attributes should not be forgotten and while constructing a workable relational framework is vital to those conditions, the role of territory and the existing powers held by local government are also crucial.

The Regional Development Agency (in this case, the East Midlands Development Agency, (EMDA)), was able to build a reasonably successful governance network and contribute positively to the region's economy (PWC 2009, ECOTEC 2009). Despite this, 
throughout its time in operation EMDA failed to establish itself as the leader of the region's economic development efforts and singularly failed to engage the population (either public or business) of the wider region. Indeed, towards the end of its lifespan EMDA increasing shied away from such a role preferring to launch new agencies through which to implement its strategies. This, along with territorial factors, meant that EMDA struggled to attract significant involvement from the local business community, particularly from outside of its Nottingham base. This contributed to questions about the legitimacy of an agency working at the regional level in a region without any sense of coherence or identity and a lack of political leadership.

The Labour Government carried out a Sub-National Review (SNR) of economic development in 2007. As a result, the role of the regions local governments was increased in local economic development to noticeable success in two areas, Leicestershire and Corby. Both areas could claim to be areas of economic functionality in their own right, while the East Midlands economy did not function as a single economy but as several competing ones. However, although other areas of the region (Northampton and Nottingham for example) could also be seen as areas of economic functionality progress in these areas was much slower. The main reason behind this difference in outcomes was the role played by local leaders from local government in driving the agenda in their areas and being able to demonstrate the advantages of engaging in governance to their local populations. In both Corby and Leicestershire private sector involvement was greater than at the regional tier and in both areas respondents from the private sector attributed this to the role of the political leadership in their areas. The involvement of 
local government added an air of legitimacy and gave a mandate to local economic development efforts that EMDA could never manage. The establishment of the LEPs and elected mayors (in the case of Leicester) has had mixed results for leadership in Corby and Leicestershire. Conversely the addition of the new Northamptonshire LEP has had far greater success in establishing itself as a leader of its local economy than its predecessors.

The paper will conclude by discussing the implications of this for leadership at the local and regional tiers. The initial success in Leicestershire and Corby and subsequent improvements in Northampton happened because local leaders emerged with support of the local government sector working on a recognised and supported geographical area. Where that process didn't occur attempts to establish a social contract between public and private sectors struggled to get off the ground. The impact those leaders had is too important to leave the emergence of future local leaders to chance. At a time when the focus in policy debates have shifted further to the local from the regional a more formal role for local government may be welcome, however there are issues regarding identifying potential local leaders and then keeping them in the local sphere long enough to have an impact that need to be addressed.

\section{Methods}

This paper presents findings from two stages of research into the East Midlands, Leicestershire and Northamptonshire. Firstly, the paper uses data from a series of 29 in 
depth interviews carried out during 2009 that examined the work of the East Midlands Development Agency at both the regional and sub-regional tier (Quinn 2013). These interviews included an in-depth case study of EMDA, local politicians, representative from the private sector and local community groups. Secondly it uses data from a follow up study of the establishment of the Local Enterprise Partnerships (LEPs) in Leicestershire and Northamptonshire (Quinn 2013, 2014), this second stage was more ethnographic in nature making use of the authors role on the Leicestershire LEP research board and documentary analysis from both the Leicestershire and Northamptonshire LEPs.

\section{Leadership and Place}

Attempts to drive economic development through place based policies have met with varied success (as the debate on uneven development demonstrates (Hudson 2007, Pike \& Tomaney 2009)) and several reasons have been put forward for this such as the preexisting economic conditions, the supply of labour and skills and the boundaries chosen. These are linked to the regional governance arrangements put in place and their suitability for encouraging growth but as Collinge and Gibney (2011) point out, the issue of leadership within the new regional governance structures has, largely, been ignored with one or two exceptions such as Czepczynski (2009). While policy debates have focused on the 'hard' elements of governance such as the functionality of institutions and networks that have been established they have left out the 'human touch' (Collinge and Gibney 2011), which can provide vital impetus to an areas economic growth initiatives. 
Collinge and Gibney (2011) argue that any study into the effectiveness of governance networks cannot afford to separate out the contribution of leadership to its success or the implications and consequences of a lack of leadership. Related to this Pares et al (2014) also point to the importance of place in setting up urban governance networks and how a lack of understanding of the local government conditions can lead to a failure of neoliberal regeneration efforts.

Sotarauta et al (2012) argued that studies of leadership at the local and regional tiers need to do more than merely describe incidents of individual successes. Leadership scholars must strive to identify the factors that enable leaders to lead and, crucially, that create the capacity for that leadership to become embedded in its locality. As the example from Barber and Eastaway (2011) below demonstrates the dangers of relying on individuals can be that leadership quickly disappears once a person moves on. In defining leadership capacity Sotarauta et al (2012) identify the qualities of sustainability, resilience, social embeddedness and renewability as crucial factors in building leadership capacity at the local tier. In terms of the Social Contract the element of sustainability and embeddedness are of most interest here, what might a leader have to offer in order to gain the level of sustainability that Sotarauta et al seek?

Barber and Eastaway (2011) examined regeneration projects in the Eastside district of Birmingham (Eastside) argued that the regeneration attempts of the past 20 years demanded a new type of leadership due to the collaborative demands of partnership working between the public and private sectors. The Eastside development of a deprived 
area of Birmingham involved a partnership of the local business community, the City Council and the RDA (Advantage West Midlands, AWM). The initial phase of the development saw broad plans that combined the physical regeneration of the land with social projects such as a new central library for the local people. The funding was largely provided by AWM but the lead and drive came from two individuals at the City Council - the then Council Leader and the Head of Economic Development. Through the relationship that these two individuals had built up with the local business community they were able to combine the social and economic agendas together in a single project. However, in the Local Government Elections of 2004 the political leadership of the City Council changed hands and much of the impetus for the social side of the project was lost leading to the scrapping of the proposed new library. One of the issues that arose was that the leadership role that the Council undertook prior to 2004 was never formally written into the structure of the Eastside partnership and when the two key leaders lost their position there was no-one prepared to take their place.

The key lesson here seems to be that there is a need to establish which partner body is responsible for the strategic leadership of a development project at the outset rather than relying on one or two individuals to come forward. In addition, the location (as in which partner organisation they represent) of those leaders is vital to a development project that encompasses both economic and social elements as community engagement is simply not a priority for some stakeholders - and nor should it be expected to be of the business community. 
Barber and Eastaway (2011) cite the development of the 'Barcelona Model' of Governance by Monclus as a useful method of attracting sufficient community and business involvement in a regeneration project and the role of Local Government in driving this model and providing political power and legitimacy is key. From this the project was able to gain citizen involvement and gain local business support which enabled the City to press ahead with the urban, economic and social refurbishment of the Poblenou district of the City (named 22@) (Barber and Eastaway 2011).

\section{Figure 2: The Barcelona Model}

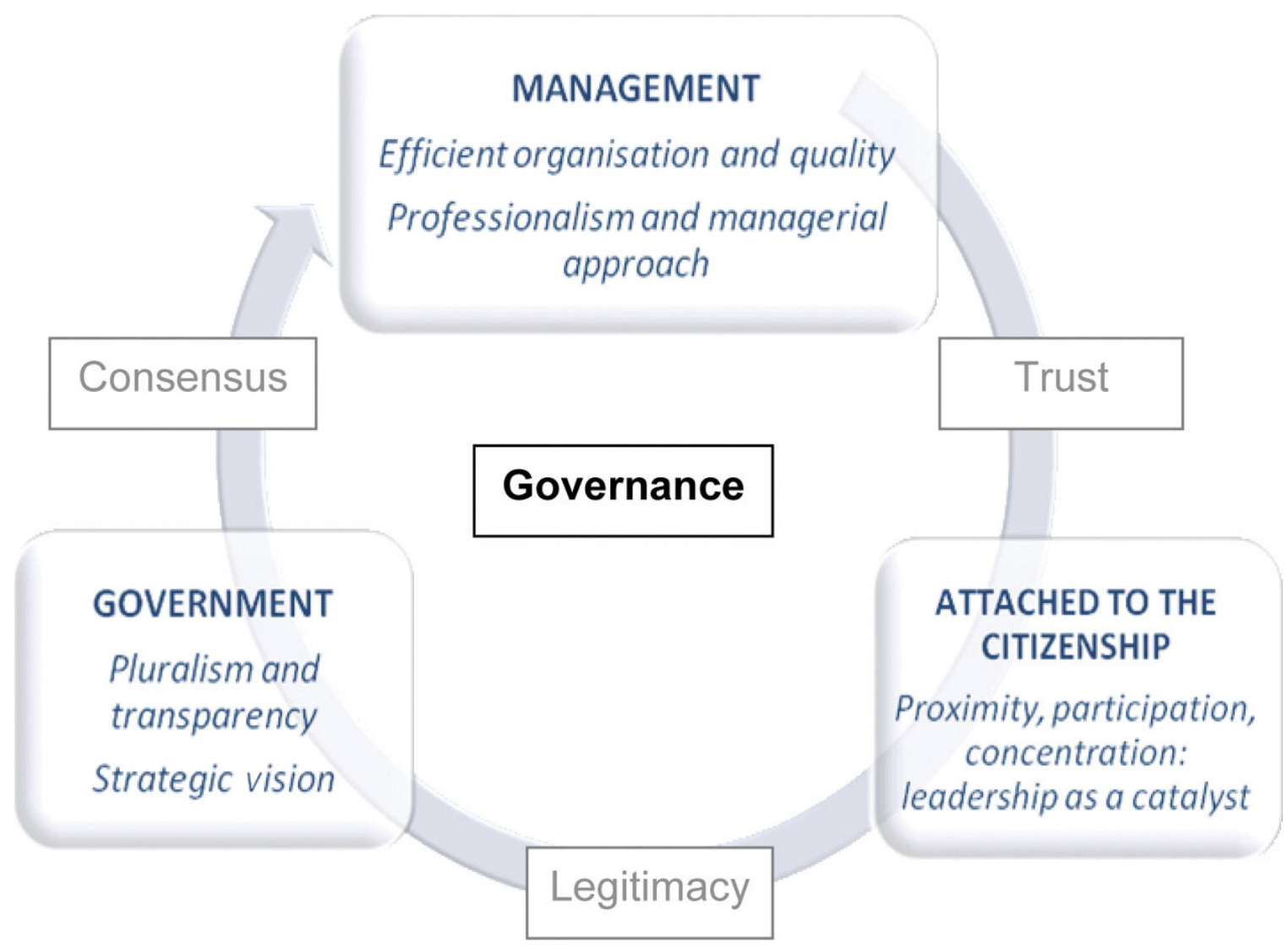

Barber and Eastaway 2011 pg 36 - based on Monclus 2003 
This model of Governance adds to the work of Cooke and Morgan (1998) by taking the concept of trust and the ideas of partnerships and adding a sense of legitimacy to it. There are also clear links with Sotarauta's (2002) word on typologies of local leadership and the implications for local leaders of neoliberal networked governance initiatives. Sotarauta (2002) argued that as power in governance networks is shared across several different actors a new kind of local leadership is required. Leaders can no longer merely rely on the Powers they may possess from statutory legislation, they also need to be able to influence and persuade other actors that they are worth following. Here Sotarauta distinguishes between the ability to 'force' a move and the ability to 'seduce' other actors into following a lead. In the East Midlands, it became clear that EMDA struggled to 'seduce' the region whereas the local government tier had much more success persuading local actors to follow its lead.

Re-Examining the East Midlands Through the Lens of the Social Contract

The next section of this paper will use Social Contract Theory to re-examine the leadership lessons drawn from the East Midlands of England between 1998 - 2015. This section covers three distinct periods of English sub-national policy - the RDA's (1998 2007), the period following a sub-national review of economic development during which the Leicestershire MAA was set up $(2007-2010)$ and finally the abolition of the RDAs and setting up of the LEPs and office of Elected Mayor in Leicester (2010 - 2015). This involves shifting between the tiers of the Region and the County/City_Region as dictated by the direction of policy. The role of local government in the various stages of 
development in the East Midlands and Leicester covered by this study also changed significantly throughout the period. Their ability to lend legitimacy to economic development efforts and take a leading role will be explored further in the following sections.

1998 - 2007: EMDA and the East Midlands - A Struggle to Establish a Contract with the Region

The East Midlands Development Agency (EMDA) was one of eight Regional Development Agencies (RDAs) set up in England in 1998. It was charged with developing a region wide strategy aimed at growing the East Midlands economy. EMDA did have some notable successes and was, before its abolition, able to point to several reports (EEF 2007, PWC 2009, ECOTEC 2009,) showing its positive impact on the region's economy. Despite this it struggled to establish itself as a regional leader, especially outside of its Nottingham base. Businesses and other public sector actors from the rest of the region expressed a reluctance to work with EMDA and did not see them as a legitimate leader. There were several reasons for this but the main issue was that the region itself was not seen as a coherent territory, this had enormous impact on EMDA's ability to form a contract with the region's population and business community (Quinn 2015). The East Midlands cannot be viewed as a functional economic region; instead there are at least four economic regions within the East Midlands competing with each other (Champion et al 2007, Quinn 2013, 2015). The success or failure of the economies of Northampton and Leicester had little, if anything, to do with the economic 
performance of Nottingham or the rest of the region. Thus, the RDA was unable to demonstrate that it could offer economic protection to many parts of the region. The difficult nature of the region was problematic for EMDAs attempts to work at the subregional level and as an agency they struggled to establish a mandate to lead the region (Quinn 2013).

Alongside the problems with the region EMDA was also a reluctant leader, preferring to see the Regional Economic Strategy as being driven by the regions business community and belonging to the region. When examining the broad range of projects, policies and strategies that EMDA offered it became apparent that the agency was reluctant to use its own name. Instead various initiatives where launched as (for example) the East Midlands Science Council, East Midlands Innovation, the Business Link, INETS, and the various SSPs (see www.emda.org.uk). Each of these was funded to one extent or another by EMDA, but uses a different name and badge. In some instances, the EMDA brand was completely absent.

EMDA argued that this was done in an attempt to ensure their services had an air of credibility. So, linking the innovation to the Science Council was seen as a way of proving to potential partners that the innovation strategy was a credible policy approved by leading experts. However, the impact was that EMDA was not seen as an active actor in the economy and so their attempts to lead on innovation floundered as Businesses were unwilling to sign up to their efforts as the benefits were not clear. 
One area in which EMDA was able to take a firm lead was in its dealings with the smaller towns and districts in the East Midlands. In Corby, the agency worked with Local Government and local businesses to lead the re-development of the town. Corby was a 1960s new town development whose growth was centred on large steelworks and an influx of workers from Scotland. The steel plant closed in the 1980s and the town has since become one of the most deprived in the region with high levels of unemployment. In recent years, however, attempts have been made to reverse the decline with ambitious new business developments put in place. EMDA provided leadership and political influence to these regeneration efforts along with the local council and business community in a group called 'Catalyst Corby'. Through this initiative, a new mainline railway station was opened in 2009 that connects the town to London, Leicester and Nottingham. In addition, the development of the 'Corby Cube' - a new town centre leisure facility - and the rebuilding of the towns retail outlets have given the towns economy a significant boost. The Council has taken the opportunities created by the new rail link to attract exhibitions and conferences based around the logistics sector. During the fieldwork for the first stage of this research in 2009, a conference for the construction industry had brought in an estimated $£ 3$ million to the local economy. EMDA was credited for playing an active, and vital, leadership role in this redevelopment:

We regard EMDA as being, you know, very important in terms of what they've done in Corby. You know, they too have a seat on the NNDC as well. So we're probably at a bit of an advantage because of that. 
we would argue that they've had a positive impact in Corby. And you only have to look around at the sorts of things they've been investing in to see that we have been delivering. Things like the railway station which has opened much earlier than people anticipated, you know, the theatre is progressing really well.

(Local authority respondent)

Overall EMDA was more successful when working at the local level with the borough and district councils. At the County and City region tier EMDA was not welcomed in the same was as they had been in Corby and their involvement was seen as a hindrance to local economic development rather than providing leadership. There are two explanations for this, was is that EMDA was never seen as a legitimate actor in the Cities and that the Cities felt they were big enough to go it alone. The second reason was more of EMDA's own making, they consistently ignored the wishes of the larger authorities to the extent of pointedly excluding City and County Councils from their sub-regional bodies. Sotarauta (2002) and Stimson et al (2009) both discuss the importance of successful leaders being flexible enough to share power and information and on this issue EMDA was found wanting.

The 2007 Sub-National Review (SNR) of economic development efforts criticised the RDAs for not working closer with local authorities. In the East Midlands, the result of this was that EMDA was forced to devolve more funding and decision-making powers to the County and City authorities within the region. In Leicestershire, this opportunity was 
seized enthusiastically and the next section of the paper will examine how the local authorities and key individuals led the economic development of Leicestershire between 2007-2010.

2007 - 2010: Emergence of a willingness to lead/leadership capacity

The implementation of a Multi-Area Agreement (MAA) in Leicestershire was the result of a combination of strong leadership being provided by both the public (City and County Councils) and the private sector in Leicestershire. The signing of the MAA was a landmark event and one that emphasised the progress being made in the county, compared to other areas in the region up to 2010 . The MAA document talked broadly about having a clear focus on economic development and increasing the skill levels and employment opportunities in the sub-region (see www.leicester.gov.uk for details). To put these ideas into practice, the two upper-tier authorities joined together to form a new sub-regional governance structure (see Figure 3). The new structure differed from the old Sub Regional Partnership with EMDA in several ways, not least because economic development per se was just one of the delivery objectives of the MAA. Crucially, as can be seen below, the structure was headed by a leadership board which included the political leaders of the City and County Councils, as well as representation from the newly formed Leicestershire Business Council and other key local actors. Each of the actors involved in this initiative had clear roles assigned to them. The Business Council was formed to try and ensure that the interests and views of the private sector are central to the strategy produced for the county. The private sector made up a significant 
proportion of the leadership board, as the councils were keen to ensure that the economic development of the sub-region was business-led. Below the leadership board was a coordination board which is run by the chief executives of the councils and the economic development teams in each council. EMDA had a seat on the coordination group as well. The leadership and coordination groups are responsible for coming up with the vision and strategy to drive Leicestershire forward, and the delivery of this strategy is then undertaken by five different delivery vehicles: employment and skills, business and enterprise, transport, housing, planning and infrastructure, and finally, rural partnerships. The key strength of this new structure was establishing a clear hierarchy in the county with the various elements reporting to, and being held accountable by, an overarching leadership board which could ensure that a single strategy drives each policy board.

\section{Figure 3 Leicestershire sub-regional governance structure}

\section{NEW SUB REGIONAL STRUCTURE}

(as at $14^{4^{\text {th }}}$ January 2009)

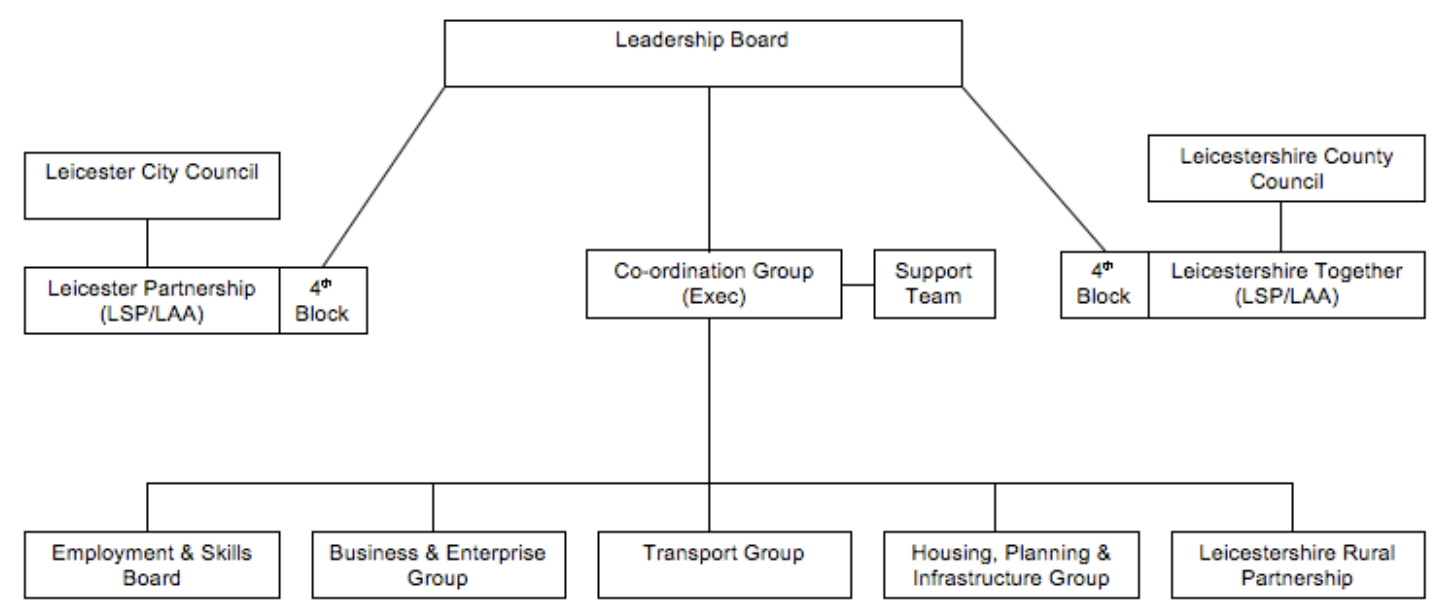

Source: Diagram provided by Interviewee 
Each of these delivery vehicles had a separate budget with which to fund its own projects, and it is here where the structure was markedly different from the existing set-up within both the county and the East Midlands as a whole. This structure enabled the leaders of the sub-region to come up with a coherent plan for the area and then control how that is delivered in terms of planning, transport, skills and economic development, whereas the LSEP and to a large extent EMDA could only influence delivery in economic development. The plan produced by the MAA contains some striking similarities to the original plans for RDAs and assemblies that were put forward by John Prescott when Labour were in opposition (Regional Policy Commission 1996), with a single over-seeing body producing policy for various delivery bodies to implement instead of the messy national solution that saw vital skills, economic, planning and transport decisions being taken by different bodies within the same region.

In a number of interviews the partnership building was attributed to the political leaders of the two councils who were prepared to work with each other in order to put the MAA together. This gave impetus to leadership efforts and here we can see that it helped to convince local businesses to engage with local economic development. The following quote is typical of the opinions being expressed in the interviews from people with no connection to either man. Indeed, the importance of key individuals emerged as a leading factor in the success of the Leicestershire sub-region. 
from the point of view from having a Tory county council working with a Labour city council, that's pretty impressive really. And this isn't a party political point at all but I think ...(the two leaders)... deserve a lot of praise in terms of, to some extent, burying their political differences, identifying the need that city and county do need to work together.

(Leicestershire private sector respondent)

This spirit of cooperation and recognition that the two authorities need to work together extends beyond the political leadership to the bureaucratic leaders of the two authorities and their teams. It is vital to get both the politicians and the civil service working together as a lack of such cooperation was cited by respondents in Nottinghamshire and Northamptonshire as a leading factor in the lack of progress towards a MAA or even successful LAA in the area of economic development.

The chief execs, the deputy chief execs... they are genuinely rolling their sleeves up and getting involved and working on projects all the time, ... the biggest legacy of this change would be that city and county officers get used to working together and continue to do so going forward because they've got so much in common in terms of the issues that they are dealing with.

(Leicestershire private sector respondent

The involvement of the two upper-tier authorities was seen as key to the success of the MAA and the new governance structure in the sub-region. At the heart of that success are 
a handful of key individuals from the local authorities themselves and additionally from the business community who recognised the need to work in partnership together to drive the local economy forward for the benefit of all. This is a similar finding to the research of Czepczynski (2009) in Gdansk and Gibney et al (2011) in Birmingham, Barcelona and others. Czepczynski (2009) found that attempts to stimulate growth at the regional level in Poland were floundering in the tri-city area until key individuals emerged in Gdansk who were prepared to take on a leadership role and drive things forward. There is little doubt that the two people who consistently attracted the most praise from respondents were the two political leaders of the councils who forged an effective working relationship despite their political differences, and have enabled Leicestershire to become one of the leading examples of local economic partnerships. Respondents from the private sector were keen to praise both men:

the leader of the Leicester city council, ... I believe he has plans or he has a desire for the city to improve. Yes, he is by far the best local council leader that I have seen in the last 20/30 years. The leader of the county, he's a prickly and a difficult character but very firm and direct and I respect him hugely for that, if he doesn't agree with you he'll tell you straight away.

(Leicestershire private sector respondent)

It is important to stress that the aim here is not to highlight the actions of certain individuals for praise but is concerned with identifying the benefits of having such strong local leadership in a sub-region. Instead it emphasises the fact that business simply will 
not get involved in local partnerships if they feel the local authorities or RDA responsible for them are not up to the job or that they are not taking business interests seriously. Viewed in terms of a Social Contract we can see that business involvement in local partnerships is voluntary and therefore must be worthwhile otherwise they will walk away. It was apparent that the involvement of a strong local authority lent the partnerships an air of legitimacy and bred confidence in the business community that here was a local economic partnership with teeth and the ability to actually get things done.

The role the political leaders played in Leicestershire gave and incentive for private sector individuals to become actively involved in the MAA set-up. They felt that they could work with them and wouldn't be wasting their time. Other local authority respondents were also quick to offer their opinion that the driving force behind the progress in Leicestershire had come from the two leader's willingness to work together:

despite the fact they are of opposite political persuasions, the attitude that ...(the two leaders)... have is very similar in terms of what their role is. You know, they want to lead the community, not just lead the council, and recognise that in economic development terms and in quite a lot of areas, they do need to work very much together because of the geography of the area.

(Local authority respondent)

Of course, the potential problem of relying on a small number of key people is that the structures put in place may not survive one or more of them leaving their positions. As 
Sotarauta et al (2012) discussed renewability is crucial to leadership capacity so the roles of key positions rather than individuals need to be clearly understood. In the case of the two Council leaders, they are at the mercy of the ballot box and a future election could well return the Liberal Democrats or Conservatives to power in the City which, given the previous experience of those two groups in charge, would not breed confidence.

Although the City leader failed in his attempt to win a parliamentary seat at the 2010 General Election he did relinquish the leadership of the City Council soon afterwards and the City now has its first elected mayor which changes the political landscape, something respondents were wary of;

And you know that happened before and we happen to be in a position at the moment where we've got two strong and charismatic leaders who've got who've led the way on this and as I said before buried their political differences and worked together. If that were to change tomorrow I would have some concerns as to do we go... we might go back to the dark ages.

(Private sector respondent)

Clearly, then, the new structures needed time to bed in and it is to be hoped that they can survive the loss of one or more key individuals if they are to be sustainable in the long term (Sotarauta et al 2012). Leicestershire is an interesting example of what a strong and involved local authority can achieve. In addition to the risk of losing key individuals, there is also the issue of how to design a policy that can identify these potential civic leaders. How can policy-makers ensure that the success stories in Leicester, Gdansk 
(Czepczynski 2009), Barcelona and Groningen (Gibney et al 2011) are more than sheer luck that the right people emerged at the right time?

The evidence from Leicester and Leicestershire showed the positive impact the involvement of Local Government and local leaders can have on local economic development efforts. Other areas of the East Midlands such as Nottinghamshire and Northamptonshire can also be described as functional economies and have the same territorial cohesion as Leicestershire but between 2007-2010 leadership in these areas failed to emerge in the same way as it did in Leicestershire. Respondents from those areas where quick to point to the lack of engagement from their Local Authorities as a factor in this.

not to be too unfair to our political leaders but there is a significant lack of a real, dynamic leadership in Northamptonshire, it's not one of those places where I think there's a leader who grabs the bull by the horns and pulls everybody along with him.

(Northamptonshire respondent) 2010 - 2015: Local Enterprise Partnerships, Elected Mayors and Leadership - Contract Renewed-Contract Stalled?

The 2010 General Election brought with it significant changes at the sub-national tier in England. One of the first acts passed by the new Government saw the abolition of the RDAs and the regional tier disappeared from the policy lexicon. Local Enterprise 
Partnerships (LEPs) were established with the aim of moving decision making and partnerships down to the City Region or County level. In the East Midlands four LEPs where established (Derby \& Nottingham, Leicestershire, Lincolnshire and Northamptonshire). In theory, this move made sense and certainly the evidence from Leicestershire suggested that this was the right tier at which to operate and at which effective local leadership might emerge. In Northamptonshire, significant improvements in the relationships between the public and private sector have seen the Northamptonshire LEP establish itself as one of the more effective LEPs in England garnering praise from Government for its work. The LEP produced an economic strategy for the County based on its high performing motorsport industry and in a complete turnaround from the inactivity of the local council during the RDA period this has been led by the Town and County Councils. Indeed, the work of the Northamptonshire LEP has been identified as the most enterprising in England with the County Council being singled out for praise.

Northamptonshire County Council has shown real initiative in reinvigorating the local economy through a range of positive schemes. They have shown complete support for the newly formed Northamptonshire Enterprise Partnership.

Business Minister Michael Fallon, BIS Press Release $20^{\text {th }}$ September 2012

There is little doubt that the LEP in Northamptonshire has done some impressive work since being established and has tapped into the existing strong economic base in the County to build a sense of identity and leadership. However, the improvements in the Northamptonshire networks haven't included Corby to the same extent that EMDA did. 
Indeed, the Northamptonshire LEP could rightly be criticised for 'backing winners' (Pugalis 2010) rather than developing strategies to overcome weaknesses in its economy (Quinn 2014).

Back in 2009, a move to county- or city-level intervention was a cause for concern in Corby with the fear being that they would no longer be a priority case in any new, more local arrangements. They feared the was the potential for them to be left out of the new arrangements made between city and county Councils (or in their case between Northampton and Northamptonshire) in order to focus on city and major town developments. These interviews were carried out before the Conservatives (then still in opposition) had finalised their plans for economic development at the sub-national level, but respondents from Corby did voice concerns about the removal of the regional (in their case protective) tier.

It'll be a huge problem for us because I suspect that what they would to is they'd start channelling funding back through the county councils and so on...when we go through the county council them politics will come into play and we are the one Labour area and likely to remain the one Labour area within a sea of blue. So you know, we would seriously worry about the level of investment in future.

(Local authority respondent)

In Leicestershire as well as the establishment of the LEP the City also introduced an Elected Mayor for the first time. Both the LEP and the City Mayor created their own 
economic development teams which ran alongside those already in place in the City and County. The leader of the City Council who had been highly praised for his role in leading the MAA ran for Labours Mayoral nominee but was defeated by the local MP who ultimately became Mayor. At the same time the leader of the County Council stepped down while the Chair of the local Chamber of Commerce who had led business engagement with the MAA retired. These changes have seen leadership in Leicestershire fragment somewhat with co-operation between the City and County stalling since 2010 . Work that had been on-going on integrating the public transport network has slowed considerably since the LEP replaced the MAA which is having a significant effect on travel to work times between the County and City and making it especially hard to get qualified workers out to key employment locations in the County such as the Meridian Enterprise Park and the MIRA road safety testing facility in Hinckley. The Mayor's role is limited to the City boundaries that does not map onto the economic footprint of the City which stretches across the County. Shutt et al (2014) found similar issues emerging in Liverpool and Bristol where the Elected Mayor's remit does not cover the whole economy. There is a case for City Mayors to have their boundaries extended to CityRegions to enable them to take a leadership role across the whole economy. Despite this there is considerable evidence that the Elected Mayor in Leicester has been successful in establishing a contract with the City of Leicester, if not the wider County. Turnout at the two elections to date (41\% in 2011 and 59\% in 2015) have been impressively high. The Mayor is widely recognised as the leader of the City and the political powers that the position when it was created have made it much easier for the Mayor to persuade local people and business to follow his lead. 
Leicestershire's experiences since 2010 do offer some good news for sustainable leadership however. While there are now four (City, County, LEP and the Mayor) separate bodies vying for economic leadership within the County the principal of strong Local Government involvement has survived the loss of the MAA and the key individuals from the post SNR period. The private sector in Leicestershire is still more involved in local economic development initiatives than during the EMDA period and the leadership role of Local Government is widely accepted. This can be seen in the continued programme of Cultural and Heritage development in the City which has combined the efforts of the private sector, City Council and the local Universities to complete the physical regeneration of the City around a new Theatre district and heritage trail.

The evidence from the LEPs in Northamptonshire and Leicestershire concerning leadership suggests that they are in a better position to provide leadership than the RDA was due in the main to the fact that they cover single areas of economic functionality. In both cases more needs to be done to fully embed the leadership roles of the various agencies that operate within the Counties but it is clear, especially in the case of Leicestershire, that there is an acceptance that Local Government has a leadership role to play. 


\section{Conclusions}

Social Contract Theory offers a useful lens through which to draw out lessons on

leadership of place and, crucially, engagement with that leadership. The lessons from the East Midlands show that territory, the presence of political power, the use of areas of economic functionality and the role of key individuals can all help to produce the conditions under which local people and businesses might be prepared to sign a contract with local leadership. Here we can bring classic Political Theory together with more modern regional scholarship in the form of Sotarauta et al's (2012) required factors for building regional leadership capacity (sustainability, resilience, social embeddedness and renewability) to use the examples from the East Midlands to offer some thoughts on how we might use these lessons in our wider understanding of regional or place leadership. Several issues need to come together for the social contract to be signed and for sustainable leadership to embed at the sub-national tier. They are; 1 . An appreciation of the role of key individuals. Policy makers need to find a way of identifying potential local leaders and, crucially for sustainability, also providing the incentives to keep them involved at the local tier. 2. An agreed sense of place/territory within which leadership can embed itself (this is a twofold issue, if place isn't 'real' then leadership ignored, it if powers don't cover whole area (e.g. elected mayor) then they can't be effective). 3. An understanding that Local Government adds legitimacy (or resilience) to governance and leadership efforts. The RDA struggled because it wasn't seen as a legitimate actor in the local economy, and 4. That there needs to be a clear understanding of the roles various actors play and which organisations are responsible for leadership. Leadership roles 
should be fixed and tied to organisations not individuals if leadership is to be sustainable and renewable.

Acknowledgements

The author would like to thank the Local Economy reviewers for their constructive feedback on the initial draft of this paper and the attendees of the RSA Network in AixMarseille for their feedback at the workshop.

References

Barber, A. \& Eastaway, M. (2011) Leadership Challenges in the Inner City: Planning for Sustainable Regeneration in Birmingham and Barcelona; in Collinge, C., Gibney, J., \& Mabey, C. (2011) Leadership and Place, Routledge, London

Barker, E. (ed) 1960, Social Contract, Oxford Press, Oxford

BIS (2012), Enterprising Britain Awards 2012 Winners Announces, Department for Business, Innovation and Skills Press Release www.bis.gou.uk/enterprising-britain accessed 27th January 2013

Blanco, I., Griggs, S. and Sullivan, H. (2014) Situating the Local in the Neoliberalisation and Transformation and Urban Governance, Urban Studies 51 (15) 3129 - 3146 
Boucher, D. and Kelly, P. (eds), The Social Contract from Hobbes to Rawls, Routledge, London

Champion, T., Coombes, M. G., Raybould, S. R. and Wymer. C. (2007) Migration and Socio-economic Change: A 2001 Census Analysis of Britain's Larger Cities, Bristol, Policy Press.

Collinge, C. \& Gibney, J. (2011) Connecting Place, Policy and Leadership, in Collinge, C., Gibney, J., \& Mabey, C. (2011) Leadership and Place, Routledge, London

Collinge, C., Gibney, J., \& Mabey, C. (2011) Leadership and Place, Routledge, London Czepczynski, M. (2009) 'Regionalisation in the Gdansk area', International Journal of Public Sector Management 22(3): 249-59.

Cooke, P. and Morgan, K. (1998) The Associational Economy: Firms, Regional and Innovation, Oxford, Oxford University Press.

ECOTEC (2009) Evaluating the Impact of the East Midlands Development Agency, Birmingham, ECOTEC.

EEF (2007) Improving Performance? - A Review of Regional Development Agencies, London, EEF. 
Etherington, D. and Jones, M. (2009) 'City-regions: new geographies of uneven development and inequality', Regional Studies 43(2): 247-66.

Hobbes, T. (1991)) Leviathan, Cambridge, Cambridge Press

Hudson, R. (2007) Regions and Regional Uneven Development Forever? Some Reflective Comments upon Theory and Practice, Regional Studies 41:9 pp 1149 - 1160

Jones, M. (2014) New New Regional Geogrpahy, presented at the 2014 Regional Studies Association Annual Conference, Izmir, Turkey $15^{\text {th }}$ June 2014

Lessnoff, M. (1986) Social Contract, London, MacMillan

Locke, J. (1980) Second Treatise of Government, Cambridge, Hackett Press

Pares, M., Marti-Costa, M., and Blanco, I. (2014) Geographies of Governance: How Place Matters in Urban Regeneration Policies, Urban Studies 51 (15) 3250 - 3267

Pike, A. and Tomaney, J. (2009) 'The state and uneven development: the governance of economic development in England in the post-devolution UK', Cambridge Journal of Regions, Economy and Society 2(1): 13-34. 
Pugalis, L. (2010) Looking Back in Order to Move Forward: The Politics of Evolving Sub-National Economic Policy Architecture, Local Economy 25 (5): 397 - 405

PWC (PriceWaterhouseCoopers) (2009) Impact of RDA Spending - Regional Annexes, London, BERR.

Quinn, M. (2013) New Labour's Regional Experiment - Lessons from the East Midlands, Local Economy 28 (7-8): $738-751$

Quinn, M. (2014) Leading Success: Establishing Leadership and Governance in a 'Successful' Economy, in Pugalis, L. \& Liddle, J. (eds) (2014) Contemporary Issues in Entrepreneurship Research Volume 3: Enterprising Places: Leadership and Governance Networks, Emerald, London

Quinn, M. (2015) The Impact of Place on Policy Outcomes, Regional Studies Regional Science 2(1) $229-235$

Regional Policy Commission (1996) Renewing the Regions, Sheffield, Sheffield Hallam University Press.

Rousseau, JJ (1973, Social Contract and Discourses, London, Everyman 
Shutt, J., Bentley, G., \& Pugalis, L. (2014) Changing Directions? Leadership for Economic Growth, Planning and Transport in England, paper presented at Regional Studies Association Annual Conference Dokuz Eylul university, Izmir, Turkey 16-18 June 2014

Sotarauta, M. (2002) Leadership, Power and Influence in Regional Development, in Sotarauta, M. and Bruun, H. (eds) (2002) Nordic Perspectives on Process-Based Regional Development Policy, Stockholm, Nordregio

Sotarauta, M., Horlings, L. and Liddle, J. (eds)(2012) Leadership and Change in Sustainable Regional Development, London, Routledge

Stimpson, R., Stough, R., and Salazar, M. (2009) Leadership and Institutions in Regional Endogenous Development, Cheltenham, Edward Elgar 